\title{
Financial Anxiety and Resilience among Rural Poor: An Exploration of Social Work Implication
}

\author{
Sachin B $\mathbf{S}^{1}$ (D), Ramesh $\mathrm{B}^{2}$ (D) , Saravana $\mathrm{K}^{3}$ (D), Rajashekar $\mathrm{C}^{4}$ (D) \\ ${ }^{1}$ Department of Social Work, Bengaluru City University, India \\ ${ }^{2}$ Department of Studies and Research in Social Work, Tumkur University, India \\ ${ }^{3}$ Department of Social Work, Kuvempu University, India \\ ${ }^{4}$ Department of Social Work, Ramanagara PG centre, Bangalore University, India
}

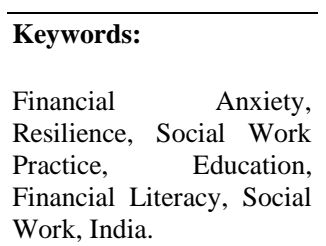

Received Date:

26-07-2021

Accepted Date:

18-09-2021

Publication Date:

30-09-2021

\section{ABSTRACT}

Purpose of the Study: Financial literacy is the main challenge for the rural population of India. It also plays a vital role in the economic outlook. In India, many poor people do not have a bank account, and only a few understand the concept of financial literacy. Due to lack of financial literacy many rural poor experience financial anxieties hence the present study was taken up to know the financial anxiety and resilience behavior among rural poor.

Methodology: The present study adopted the descriptive research design 62 respondents were selected for data collection from poor rural households by adopting the purposeful sampling technique in the Kodigenahalli Gram Panchayat jurisdiction. The present study was carried to assess the level of financial anxiety and its relationship with socio-demographical aspects.

Main Findings: The present study found that financial anxiety is experienced by the rural poor, and there is a correlation between education, occupation, number of household members with financial anxiety of the respondents.

Implication: The researcher proposed the need for Social Work Intervention to address financial anxiety and financial literacy.

The novelty of the study: The present study has described the level of financial literacy and financial anxiety that exists among the rural poor in Karnataka (India) and explored the scope of Financial Social Work in addressing financial literacy and financial anxiety. Financial Social Work changes the conversation about money. It provides a different way of thinking about money and it offers a better way of working with clients around the role of money in their lives, problems and issues.
Copyright: (c) 2021. The Authors. Licensee: IJSSER. This work is licensed under the Creative Commons Attribution License.

Please cite this article as: Sachin, B. S., Ramesh, B., Saravana, K., \& Rajashekar, C. (2021). Financial Anxiety and Resilience among Rural Poor: An Exploration of Social Work Implication. International Journal of Social Sciences and Economic Review, 3(3), 2834.

doi.org/10.36923/ijsser.v3i 3.111

Read online:

Scan this QR code with your smart phone or mobile device to read online.

\section{INTRODUCTION}

Financial literacy is a vital issue for rural population (Aguenane, 2020). It also has a significant impact on the economic forecast (Hussain, Akhter, Qureshi, \& Khan, 2021). Many poor people in India do not have a bank account, and just a handful understand the notion of financial literacy. Poverty reduction and financial literacy are two critical objectives for the central government to develop the economy (Jayanthi \& Rau, 2019). Poverty produces pressures at the family level, such as food insecurity, housing, and job insecurity, among other things. These pressures may also raise the chance of mental health problems and substance abuse in parents, which lead to child abuse and neglect, with significant mental health effects for the child. Low-income areas have certain traits such as low resources, poor housing, high crime and violence rates and an ineffective school system, all connected to poor mental health outcomes (Elliott, 2016).

Social work approaches must complement the applicable theoretical constructs or models to ensure that the methods utilized by practitioners are results-oriented. The ideas and models will help a professional understand how to behave to restore group well-being. Among the most effective techniques for working with people affected by environmental challenges are ecosystem theory, adaptation theory, social network theory, empowerment theory, and the abilities viewpoint. Using resilience theory, explain how you, as a social worker, may help to increase resilience in persons experiencing financial anxiety.

\subsection{Resilience Coping Interventions (RCI)}

The resilience coping intervention model is based on the theories and ideas of stress, coping and resilience. Folkman's (2013) transactional stress and coping model defines stress as a transaction between people and their environment in which individuals discover that external demands exceed their capacity to meet demand. Many circumstances in a college student's life can be considered traumatic, such as illness, depression, academic pressures, and peer pressure. Coping encompasses 
cognitive and behavioral attempts undertaken to meet demands that tax or overwhelm a person's resources and methods differ throughout time and contexts to balance the shifting of stressful events (Folkman, 2013). According to Susan Folkman's approach, resilience can define as a resource for reducing negative stress and maintaining or attaining positive results in the face of challenges or frightening conditions (Masten, 2001). Thus resilience refers to the ability to effectively cope with harmful, difficult situations while avoiding unfavourable risk-related effects (Luthar, Cicchetti, \& Becker, 2000). Studies have shown that individual resilience can increase by promoting coping skills that facilitate adaptation in the face of adversity (Luthar et al., 2000; Masten, 2001; Steinhardt \& Dolbier, 2008). The RCI group model is intended to reduce the harmful impacts of stress by including essential components such as a strengths-based approach, group problem solving, and peer support and its concerns.

\subsection{Strengths-Based Approach}

The resilience-building perspective explains every individual in every family has a unique and ever-changing talent, abilities, and experiences. RCI community cannot only identify but also solve their problems using adaptive solutions and tools. Following the recognition and explanation of a shared challenge by the RCI community, the RCI facilitators encourage participants to identify the skills and resources of individuals and groups as alternatives for overcoming the shared challenge. RCI enables participants to jointly describe their resources and skills, commit to action within their control, and, ultimately, acknowledge and expand their resilience in the face of stress and challenges. The RCI approach to group work is based on the group's identification of needs and capabilities rather than depending on the facilitator to prescribe solutions. Malekoff (2014) emphasizes the necessity of forming groups based on member's felt needs and desires,' as well as 'decentralizing authority and delegating power to members of the community when working with teenagers and young adults. RCI encourages group members to discover their difficulties and solutions, allowing for group control and decision-making (Malekoff, 2014).

\subsection{Social Networking Theory}

The study of how people, organizations, or groups interact with others in their network is known as social network theory. Understanding the theory becomes simple when the various elements are explained, beginning with the highest factor is the network and working your way down to the smallest piece, the actor. Social scientists study three types of social networks: egocentric networks, socio-centric networks, and open-system networks. An ego-centric network is associated with a single node or an individual node. For example, you, the node, are linked to all your close friends. Socio-centric networks are taken down by nature. Two widely used examples of this form of the network are children in the classroom or staff inside the organization. In an open-systems network, the boundary lines are not clearly defined. A few examples in this type of network are the elite class of America, the connections between corporations, or the chain of influencers of a particular decision. Due to the lack of clearly defined boundaries, this form of network is considered the most difficult to research (Durland \& Fredericks, 2005).

\subsection{Family Social Work}

A family social worker assists families and individuals in overcoming adversity or obtaining more assistance. They help by informing people that they have unique services available to them, and then they go ahead and make arrangements for people to use them. It's a rewarding career since it gives you the joy of seeing people or families get back on track and restore peace to their life (Council,1998). In Western countries, a family social worker works with clients and their families. We could not witness the private practice of Social Case Work in the Indian environment. While practicing integrated Social Work in the community, Professional Social Workers tend to practice with families, particularly in their financial lives. According to numerous research, rural families have poor saving habits and do not keep accounts (Ngozi Eucharia Chukwu, 2017). Small farmers obtain money once or twice a year, and anytime they get money, they are tempted to spend it on nonproductive sources. Money temptations contribute to financial vulnerability and financial anxiety.

\subsection{The rationale of the study}

Financial resiliency is enhanced, with financial resources, such as savings, health insurance, and a good-paying job. Another resource is human capital. Economists define human capital as all knowledge, skills, experiences, contacts, and other personal qualities that people have to sell to potential employers. Individual health is part of human capital because it affects job performance and productivity. Social capital also increases financial resiliency. Financial resilience includes a support sys tem of family, friends, co-workers, neighbors, and others that can provide financial assistance, not to mention emotional support, during hard times (O’Neill \& Xiao, 2011). A significant segment of India's population (about 25\%) receives less than \$2 a day. We live in both urban and rural areas. Their unique characteristics and needs shape their everyday lives. The Indian population average, $76 \%$, does not even understand the basic financial concepts. While the idea of financial inclusion has spread to rural areas, not much of it has had any effects due to inadequate financial literacy (Wyman, 2017). Indians consider financial literacy to be significant for an adult but do not realize that if the idea of financial literacy is cultivated in the minds of a child during the learning/schooling stage itself, he/she would automatically grow up to be financially literate individual.

\subsection{Objectives of the study}

- To assess the socio-demographical condition of the households

- To ascertain financial anxiety among household members.

- To assess the impact of the socio-demographic condition on financial anxiety and Social Work responses.

\section{METHODS AND MATERIALS}

The present study is descriptive hence descriptive research design was adopted to describe the socio-demographical condition of the rural poor, to assess the financial anxiety, and draw Social Work intervention to create resilience among the rural poor. The present study was carried in Kodigenahalli Gram Panchayath of Nelamangala Block, Bangalore Rural district, in March 
2020. The primary data was collected by administering the interview schedule since the research population consists of rural poor thus, the purposive sampling technique was used. 62, structural rural poor households were chosen as samples to assess financial anxiety among them. Households Financial Anxiety assessment scale, FAS psychometric tool was used to assess the degree to which an individual experiences financial anxiety administered to assess financial anxiety at the financial anxiety experienced by the respondents (Archuleta KL, Dale A, Spann SM, 2013). Kodigenahalli Gramapanchayat Nelamangala Block is $40 \mathrm{kms}$ away from Bangalore. Also, the village is one of the border places of Nelamngala and Doddaballapura block. The villagers are not accessible to facilities like transportation and facing many more problems hence the study conducted in the village.

\section{FINDINGS OF THE STUDY}

TABLE 1

Socio-demographical background of the respondents

\begin{tabular}{|c|c|c|}
\hline Particulars & Frequency & Percentage \\
\hline \multicolumn{3}{|l|}{ Gender } \\
\hline Male & 35 & 56.45 \\
\hline Female & 27 & 43.54 \\
\hline \multicolumn{3}{|l|}{ Category } \\
\hline $\mathrm{SC}$ & 26 & 41.93 \\
\hline ST & 6 & 9.67 \\
\hline $\mathrm{OBC}$ & 29 & 46.77 \\
\hline Other & 1 & 1.61 \\
\hline \multicolumn{3}{|l|}{ Education qualification } \\
\hline Illiterate & 09 & 14.51 \\
\hline Primary Education & 22 & 35.48 \\
\hline Up to Matriculation & 25 & 40.32 \\
\hline Higher education/technical education & 6 & 9.67 \\
\hline \multicolumn{3}{|l|}{ Occupation } \\
\hline Agriculture labourer/ casual labour & 23 & 37.09 \\
\hline Farmers & 24 & 38.70 \\
\hline Skilled labourer & 05 & 8.06 \\
\hline Employee private /public & 10 & 16.12 \\
\hline \multicolumn{3}{|l|}{ Type of House } \\
\hline Kachha & 16 & 25.80 \\
\hline Semi pucca & 23 & 37.09 \\
\hline Pucca & 24 & 38.70 \\
\hline
\end{tabular}

\section{Source: Primary}

Table number 1 depicts the socio-demographical background of the respondents. The highest i.e., 56.45 percent, are male and, the remaining 43.54 percent of the respondents are female. 46.75 percent of the respondents belonged to Other Backward Community, 41.93 percent of the respondents belonged to scheduled caste, 9.67 percent of the respondents belonged to scheduled tribes, and the rest 1.61 percent of them belonged to other (General category) category. 40.32 percent of the respondents studied up to matriculation, 35.48 percent of them had primary education, 14.51 percent were illiterates, and the rest 9.67 percent of them were higher education holders. 38.70 percent of the respondents have occupied agriculture, 37.09 percent of the respondents were agricultural laborers, 16.12 percent of the private/public employees, 8.06 percent of the respondents were skilled laborers. 38.70 percent of the respondents had a pucca house, 37.09 percent had a semi pucca house, and the remaining 25.80 percent of them had a Kaccha house. From this findings, reported that majority of the respondents belongs to humble socio-economic background.

TABLE 2

Income, Expenditure, saving and a Loan Amount of the respondents

\begin{tabular}{lccc}
\multicolumn{1}{c}{ Particulars } & $\mathbf{N}$ & Mean & SD \\
\hline Number of Household members & 62 & 4.41 & 1.56 \\
\hline Income & 62 & 35258.06 & 19791.48 \\
\hline Expenditure & 62 & 29145.16 & 11392.90 \\
\hline Savings & 62 & 2912.90 & 2636.59 \\
\hline Loan & 62 & 10241.93 & 11362.05 \\
\hline
\end{tabular}

Source: Primary

The above table delineates the average members in the household, Income, Expenditure, saving, and loan borrowed mean and standard deviation of the respondents. The mean household member was 4.41 with 1.56 standard-deviation, the mean income was 35258.06 INR with 19791.48 standard-deviations, mean expenditure was 29145.16 with 11392.90 standard deviation, mean savings of the respondent households was 2912.90 with 2636.59 standard deviations, and mean loan borrowed amount among the household respondents was 10241.93 with 11362.05 standard deviations. 
During the study, it was found, the majority of the respondents spending more than $50 \%$ of their income on non-productive sources like celebrating festivities, Social ceremonies so on. And investment in insurance, education, and health were almost not considerable.

Since respondents were members of self-help groups some of the respondents used to save, many of them joined Self Help Group for borrowing loans. After borrowing, loan utilization of loan amount for the said the productive purpose was very less.

The ANOVA result clearly shows expenditure elevate high level their income, fewer savings and moderate loan borrowing attitude could see among the respondents.

ANOVA results in the social category across the income of the respondents between and within the groups. The $(\mathrm{F}=5.10, \mathrm{p}$ $<.003$ ) shows the highly significant result that means the income varies between and within the different social categories i.e. SC (Scheduled Caste), ST (Scheduled Tribes), OBC (Other Backward Categories), and general category groups.

The mean income of the Other Backward Castes respondents is high i.e, 44758.62 and respondents who belong to Scheduled caste mean income is $26,692.30$ that means $\mathrm{OBC}$ has the highest mean income whereas the scheduled caste category respondents have less mean income.

The ANOVA result shows income across expenditure, savings and loan amount borrowed by the respondents between and within the groups. The result of ANOVA ( $\mathrm{F}=88.27268, \mathrm{p}<.041)$ shows highly not significance that means the income across expenditure, saving and loan borrowed amount did not vary between and within the groups. The mean income is high i.e. 35258 and respondents' mean saving amount was less at 2912.90.

The ANOVA result delineates the Income amount across the expenditure of the respondents between and within the groups. The ANOVA result $(\mathrm{F}=4.44, \mathrm{p}>.037)$ shows a significant result that means income amounts vary between and within the groups.

The mean income was 35258.06 INR and the respondent's expenditure means was 29145.16INR, which indicates the income of the respondents was higher than the expenditure.

TABLE 3

Financial Anxiety Assessment of the respondents

\begin{tabular}{|c|c|c|c|c|c|c|}
\hline Financial Anxiety & $\begin{array}{l}\text { Strongly } \\
\text { Disagree }\end{array}$ & Disagree & $\begin{array}{l}\text { Neither } \\
\text { agree nor } \\
\text { disagree }\end{array}$ & Agree & $\begin{array}{l}\text { Strongl } \\
\quad \mathbf{y} \\
\text { Agree }\end{array}$ & Total \\
\hline I prefer not to think about my personal finance & $\begin{array}{c}3 \\
(4.83)\end{array}$ & $\begin{array}{c}4 \\
(6.45)\end{array}$ & $\begin{array}{c}6 \\
(9.67)\end{array}$ & $\begin{array}{c}18 \\
(29.03)\end{array}$ & $\begin{array}{c}31 \\
(50.00)\end{array}$ & $\begin{array}{c}62 \\
(100)\end{array}$ \\
\hline Thinking about personal finance make me guilty & $\begin{array}{c}5 \\
(8.06)\end{array}$ & $\begin{array}{c}3 \\
(4.83)\end{array}$ & $\begin{array}{c}15 \\
(24.19)\end{array}$ & $\begin{array}{c}10 \\
(16.12)\end{array}$ & $\begin{array}{c}29 \\
(46.77)\end{array}$ & $\begin{array}{c}62 \\
(100)\end{array}$ \\
\hline I am worried about all of the debt that I have & $\begin{array}{c}6 \\
(9.67)\end{array}$ & $\begin{array}{c}3 \\
(4.83)\end{array}$ & $\begin{array}{c}10 \\
(16.12)\end{array}$ & $\begin{array}{c}6 \\
(9.67)\end{array}$ & $\begin{array}{c}37 \\
(59.67)\end{array}$ & $\begin{array}{c}62 \\
(100)\end{array}$ \\
\hline $\begin{array}{l}\text { Thinking about my personal finances can make } \\
\text { I feel anxious }\end{array}$ & $\begin{array}{c}4 \\
(6.45)\end{array}$ & $\begin{array}{c}21 \\
(33.87)\end{array}$ & $\begin{array}{c}28 \\
(45.16)\end{array}$ & $\begin{array}{c}3 \\
(4.83)\end{array}$ & $\begin{array}{c}6 \\
(9.67)\end{array}$ & $\begin{array}{c}62 \\
(100)\end{array}$ \\
\hline $\begin{array}{l}\text { I get myself into situations where I do not know } \\
\text { where I'm going to get the money to "bail" } \\
\text { myself out }\end{array}$ & $\begin{array}{c}4 \\
(6.45)\end{array}$ & $\begin{array}{c}2 \\
(3.22)\end{array}$ & $\begin{array}{c}16 \\
(25.80)\end{array}$ & $\begin{array}{c}7 \\
(11.29)\end{array}$ & $\begin{array}{c}33 \\
(53.22)\end{array}$ & $\begin{array}{c}62 \\
(100)\end{array}$ \\
\hline $\begin{array}{l}\text { Discussing my finances can make my heart race } \\
\text { or make me feel stressed }\end{array}$ & $\begin{array}{c}4 \\
(6.45)\end{array}$ & $\begin{array}{c}3 \\
(4.83)\end{array}$ & $\begin{array}{c}10 \\
(16.12)\end{array}$ & $\begin{array}{c}11 \\
(17.74)\end{array}$ & $\begin{array}{c}34 \\
(54.83)\end{array}$ & $\begin{array}{c}62 \\
(100)\end{array}$ \\
\hline $\begin{array}{l}\text { I do not make a big enough effort to understand } \\
\text { my finances }\end{array}$ & $\begin{array}{c}8 \\
(12.90)\end{array}$ & $\begin{array}{c}4 \\
(6.45)\end{array}$ & $\begin{array}{c}7 \\
(11.29)\end{array}$ & $\begin{array}{c}6 \\
(9.67)\end{array}$ & $\begin{array}{c}37 \\
(59.67)\end{array}$ & $\begin{array}{c}62 \\
(100)\end{array}$ \\
\hline $\begin{array}{l}\text { I do not think I am doing as well as I could at } \\
\text { my job because I worry about money }\end{array}$ & $\begin{array}{c}8 \\
(12.90)\end{array}$ & $\begin{array}{c}2 \\
(3.22)\end{array}$ & $\begin{array}{c}9 \\
(14.51)\end{array}$ & $\begin{array}{c}11 \\
(17.74)\end{array}$ & $\begin{array}{c}32 \\
(51.61)\end{array}$ & $\begin{array}{c}62 \\
(100)\end{array}$ \\
\hline I find opening my bank statements unpleasant & $\begin{array}{c}7 \\
(11.29)\end{array}$ & $\begin{array}{c}1 \\
(1.61)\end{array}$ & $\begin{array}{c}10 \\
(16.12)\end{array}$ & $\begin{array}{c}34 \\
(54.83)\end{array}$ & $\begin{array}{c}10 \\
(16.12)\end{array}$ & $\begin{array}{c}62 \\
(100)\end{array}$ \\
\hline $\begin{array}{l}\text { I would rather have someone else I trust to keep my } \\
\text { finances organized }\end{array}$ & $\begin{array}{c}4 \\
(6.45)\end{array}$ & $\begin{array}{c}3 \\
(4.83)\end{array}$ & $\begin{array}{c}10 \\
(16.12)\end{array}$ & $\begin{array}{c}34 \\
(54.83)\end{array}$ & $\begin{array}{c}11 \\
(17.74)\end{array}$ & $\begin{array}{c}62 \\
(100)\end{array}$ \\
\hline
\end{tabular}

Source: primary

The above table shows financial anxiety exists among household respondents. The highest $50 \%$ of the respondents strongly agreed for they prefer not to think about their personal finance, $46.77 \%$ strongly agreed for thinking about their personal finance make them guilty, 59.67 percent of the respondents strongly agreed for They are worried about all of the debt that they have, $45.16 \%$ of the respondents

were neutral for Thinking about their finances can make them feel anxious, $53.22 \%$ of the respondents opined strongly agree for they get themselves into situations where they do not know they are going to get the money to "bail" themselves out,

$54.83 \%$ of the respondents strongly agreed for discussing their finances can make their heart race or make them feel stressed, $59.67 \%$ of them strongly agreed for they do not make a big enough effort to understand their finance, $51.61 \%$ of them are strongly agreed for they do not think they are doing as well as they could at their job because they worry about money, 54.83 
$\%$ of the respondents are agreed for they find opening their bank statements unpleasant and $54.83 \%$ of the respondents agreed for they would rather someone else they trust to keep their finances organized.

TABLE 4

Showing Financial Anxiety Experienced (FAS) by the respondents

\begin{tabular}{lcc}
\multicolumn{1}{c}{ Financial Anxiety Measure } & Anxiety scale score & $\begin{array}{c}\text { \% Agree or Strongly } \\
\text { Agree }\end{array}$ \\
\hline I prefer not to think about my personal finance & 4.06 & 79.03 \\
\hline Thinking about personal finance make me guilty & 3.94 & 62.89 \\
\hline I am worried about all of the debt that I have & 4.01 & 14.5 \\
\hline $\begin{array}{l}\text { Thinking about my personal finances can make } \\
\text { I feel anxious }\end{array}$ & 3.43 & 64.51 \\
\hline $\begin{array}{l}\text { I get myself into situations where I do not know } \\
\text { where I'm going to get the money to "bail" } \\
\text { myself out }\end{array}$ & 3.96 & 72.57 \\
\hline $\begin{array}{l}\text { Discussing my finances can make my heart race } \\
\text { or make me feel stressed }\end{array}$ & 4.03 & 69.34 \\
\hline $\begin{array}{l}\text { I do not make a big enough effort to understand } \\
\text { my finances }\end{array}$ & 3.96 & 69.35 \\
\hline $\begin{array}{l}\text { I do not think I am doing as well as I could at } \\
\text { my job because I worry about money }\end{array}$ & 3.80 & 70.95 \\
\hline $\begin{array}{l}\text { I find opening my bank statements unpleasant } \\
\text { I would rather have someone else I trust to keep my } \\
\text { finances organized }\end{array}$ & 3.67 & 72.57 \\
\hline Total anxiety score & 3.72 & \\
\hline Ne. LMI = & $\mathbf{3 8 . 5 8}$ & \\
\hline
\end{tabular}

Note. $\mathrm{LMI}=$ low- and moderate-income. The lowest score a respondent could have is 10 and the highest is 50 .

Table 4 outlines the results for each item on the financial Anxiety Scale (FAS), showing the mean response and the percentage of people who agreed or strongly agreed with each statement. The cumulative results show that the mean of total anxiety scores is 38.84 indicating high financial anxiety, majority of the respondents agreed with the statements on the anxiety scale. However, there is a substantial amount of variation within the results. Almost above 75 percent of respondents reported that thinking about their finances can make them feel anxious, above half were not worried about their debt, and over 69.53 percent of the respondents reported that they do not make a big effort to under their finance. At the other end of the spectrum, less than a fifth of respondents indicated. The above table indicates the highest financial anxiety among respondents in the same they are less bothered about their financial life might be lack of financial literacy one of the reason for it.

\section{DISCUSSIONS}

The research found that demographic variables are highly positively related to financial anxiety. We have found that Education status positively predictor of respondent's financial anxiety. There is a correlation between $(r=0.229)$ Educational qualification and financial anxiety (Zaimah, 2013). Also, family size $(\mathrm{r}=0.206)$ is positively related to financial anxiety. This confirms the findings of a previous study by Agarwalla (Agarwalla et.al, 2013). This means that one critical source of information and education on the financial issue for the rural respondents is family. The findings, therefore, show the effect of family education was higher financial knowledge that means lower financial anxiety. This supports the previous study by Lusardi et al. (2010) financial literacy was strongly correlated with family sophistication. It was also found the majority of the respondents were undergoing severe financial anxiety and the majority of the respondents were spending more than $50 \%$ of their income on the nonreturnable areas. To address these issues financial literacy ought to initiate by the government and non-government organizations.

Financial Anxiety in Low- and Moderate-Income Households: Findings from the Household Financial Survey by Roll, Taylor, \& Grinstein-Weiss (2016), found similar findings that, regardless of the reported absolute levels of financial anxiety, these results suggest that asset and wealth ownership plays a major role in the financial lives of low privileged families. Higher levels of financial anxiety are connected with higher levels of debt, fewer assets, and fewer financial resources to weather an emergency. Indeed, these findings reveal that LMI households lack financial slack to offer a buffer against shocks and that this lack of a buffer is strongly related to the level of anxiety expressed by these households. It's interesting to consider the nature of the relationship between worry and financial resources. Although it is quite likely that a lack of assets (particularly emergency assets) causes financial anxiety, it is also possible that something inherent in financial problems leads to lower savings levels. The research has found that financial stress and anxiety can lead to a sort of "tunneling" in one's financial life: Financial stress has been shown to result in shorter-term thinking and an inability to focus on long-term goals, obligations, and eventualities (Roll et al., 2016). This tunneling may lead households to consume income that could be saved for emergencies or long-term considerations.

\subsection{Social Work Implication}

In the present study, the majority of the respondents are undergoing financial anxiety. Thus consciousness about the financial life of a family is needed for rural poor households to have financial stability. Hence to practice Social Work with poor rural households Social Work education must have financial literacy syllabi and practical exposure during the Social Work course 
itself. Only then, the trained professional Social Worker can effectively practice with financial aspects of poor rural households. In European countries, Financial Social Work was introduced as a part of the Social Work curriculum and practice. In India, Financial social work is neither, in the curriculum of Social work, nor at the practice level. The findings of the present study demand a dire requirement of Financial Social Worker. Herewith the researcher proposes the 'Financial Social Work Model' that needs to be included in the Social Work curriculum and practice. In addition to that, Social Work education and training need to inculcate financial literacy concepts in the curriculum, so that Social Work trainees can have theoretical knowledge and practice. During their social work intervention, it will be very helpful in applying the methods of Social Work such as Social Case Work, Social Group Work and Community Organisation, Social Action, Social Work administration and Social work Research The financial Social Worker need to be appointed the by government non-government organization in community level (especially, in Financial Literacy Centres) to render financial awareness through Social Case Work, Social Group Work among rural poor households.

Reeta Wolfsohn is the founder and president of the Center for Financial Social Work, Financial, social work originally evolved from Wolfsohn's work with women and the term femonomics, a term she coined in 1997. Femonomics expanded into Financial Social Work in 2005, an approach that leads both men and women in the direction of financial wellbeing (Wolfsohn, 2014).

As Reeta explains, Financial Social Work is a "behavioral model that moves clients beyond basic needs with a psychosocial, multidisciplinary approach focused on the thoughts, feelings and attitudes that determine each person's relationship to and behavior with money." Financial Social Work changes the conversation about money. It provides a different way of thinking about money and it offers a better way of working with clients around the role of money in their lives, problems and issues.

\section{CONCLUSION}

Since the numbers of respondents were less hence the inference drawn by the study could not be able to generalize to the entire population. However, by analyzing the above findings and discussion it was necessary to introduce financial literacy contents in school and college curriculum this can be a perfect tool to promote grassroots financial literacy. Introducing children to ageappropriate comic books about money and finance, and games that teach them about financial education will be the perfect way to imbibe the idea in their minds. In order to ensure that the concept is spread across the nation, learning materials can also be translated. Also, Resilience and Coping Intervention are also some of the models to intervene to spread financial literacy. Easy way of Social Work intervention through existing Self Help Groups, Micro Finance Institutions, and youth clubs to train them to develop a financial attitude.

Resistance and resilience are inherent in all individuals and societies. Social work intervention in distressed households based on this strategy will help pave the way for people and their communities to achieve a successful recovery from financial shocks and to make the environment more sustainable. Social workers must be involved in this area of action because we are excellent agents in promoting stability in the group, thereby growing financial anxieties and household finances. In short, social workers are agents who can be present at the adult, family, and community levels, creating and constructing healthy communities in response to financial anxieties. The commitment of social work to the financial crunch offers additional value in terms of understanding the social context and a very important holistic response to crises.

\section{REFERENCES}

Agarwalla, S. K., Barua, S. K., Jacob, J., \& Varma, J. R. (2013). Financial literacy among working young in urban India. Indian Institute of Management Ahmedabad, WP, (2013-10), 02.

Elliott, I. (2016). Poverty and mental health: a review to inform the Joseph Rowntree Foundation's Anti-Poverty Strategy. London: Mental Health Foundation, 1-110.

Aguenane, N. E. (2020). Human Capabilities and Instrumental Freedoms Relationship: An Empirical Investigation. International Journal of Social Sciences and Economic Review, 2(3), 12-21. https://doi.org/10.36923/ijsser.v2i3.65

Archuleta KL, Dale A, Spann SM (2013) College students and financial distress: Exploring debt, financial satisfaction, and financial anxiety. Journal of Financial Counseling and Planning, 24(2), 50-62.

O’Neill, B. \& Xiao, J. J. (2011) Financial Resiliency Before, During, and After the Great Recession: Results of an Online Studyy. Journal of Consumer Education, 2(8), 34-43

Durland, M. M., \& Fredericks, K. A. (2005). An introduction to social network analysis. New Directions for Evaluation, 2005(107), 5-13.

Wyman, O. (2017). Accelerating financial inclusion in South-East Asia with digital finance.

http://dx.doi.org/10.22617/RPT178622-2

Hussain, A. A., Akhter, S., Qureshi, A. H., \& Khan, K. (2021). Problem-Based Learning Approach for Elementary Schools: A case study of five Years Compulsory Education system. International Journal of Social Sciences and Economic Review, 3(2), 10-14.

Jayanthi, M., \& Rau, S. (2019). Determinants of rural household financial literacy: Evidence from south india. Statistical Journal of the IAOS, 35(2), 299-304, DOI: 10.3233/SJI-180438 .

Folkman S. (2013) Stress: Appraisal and Coping. In: Gellman M.D., Turner J.R. (eds) Encyclopedia of Behavioral Medicine. Springer, New York, NY. https://doi.org/10.1007/978-1-4419-1005-9_215

Lusardi, A. E. (2010). Financial literacy among young. The Journal of Consumer Affairs. 44(2), 358-380, https://doi.org/10.1111/j.1745-6606.2010.01173.x

Luthar, S., Cicchetti, D., \& Becker, B. (2000). The construct of resilience: A critical evaluationand guidelines for future work. . Child Development, 7(1), 543-562, DOI: 10.1111/1467-8624.00164

Malekoff, A. (2014). Group work with adolescents: Principles and practice (3rd ed. New York: Guilford Press. 
Masten, A. S. (2001). Ordinary magic: Resilience processes in development. American Psychologist, 5(6), 227-238, https://doi.org/10.1037/0003-066X.56.3.227.

Chukwu, N., Chukwu, N. N., \& Nwadike, N. (2017). Methods of Social Practice. Social work in Nigeria: Book of readings. Nsukka: University of Nigeria Press Ltd, 44-59.

Nel, H. (2015). An integration of the livelihoods and asset-based community development approaches: A South African case study. . Development Southern Africa, 32:4, 511-525, DOI: 10.1080/0376835X.2015.1039706 .

Roll, S. P., Taylor, S. H., \& Grinstein-Weiss, M. (2016). Financial anxiety in low- and moderate-income households: Findings from the Household Financial Survey (CSD Research Brief No. 16-42). St. Louis, MO: Washingto University, Center for Social Development.

Council, I. o. M. a. N. R. (1998). Violence in families: Assessing prevention and treatment programs. s Washington, DC: National Academies Press. https://doi.org/10.17226/5285

Steinhardt, M., \& Dolbier, C. (2008). Evaluation of a resilience intervention to enhance coping strategies and protective factors and decrease symptomatology. Journal of American College Health, 5(6), 445-453, DOI: 10.3200/JACH.56.44.445454.

Wolfsohn, R. (2014). Practitioner profile: an interview with Reeta Wolfsohn, CMSW. Journal of financial therapy,5(1), 86-91. http://dx.doi.org/10.4148/1944-9771.1079

Zaimah, R. e. (2013). Financial behaviors of female teachers in Malaysia. Asian Social Science 9(8), 34-41, DOI: 10.5539/ass.v9n8p34. 